\title{
Acontecimento e visualidade na escola: um estudo sobre as imagens de uma ocupação imagética
}

\section{VICTOR JUNGER}

\section{Resumo}

Procuro pensar a multiplicidade de relações estabelecidas entre os praticantes e as imagens fotográficas em meio à ocupação imagética realizada no colégio, no âmbito de minha pesquisa de mestrado, tomando a sua aparição momentânea como acontecimento de criação da escola, assim como das visibilidades presididas em seus contextos. Para tanto, apenas me deterei sobre os deslocamentos e desaparecimentos das fotografias no dispositivo da ocupação, bem como acerca das rasuras e inscrições marcadas na superfície das imagens, como indícios de um território dinâmico, polêmico, e não menos poético, desta visualidade que, incessante, se faz instaurar nos espaços e tempos da escola.

Palavras-chave:

Acontecimento, Visualidade, Escola 


\title{
Happening and visuality in school: a study about the images of an imagery occupation
}

\author{
VICTOR JUNGER
}

\section{Abstract}

Looking for thinking the multiplicity of relations between practitioners and photographic images through the imagistic occupation held at the college as part of my master's research, taking its momentary appearance as a happening of school creation, as well as chaired the visibilities in their contexts. To do so, just dwell on the displacements and disappearances of the photos in the occupation dispositive, as well as about the erasures and markings to the surface of the images as evidence of a dynamic, controversial territory, and no less poetic, of this visuality that, incessantly, is made in the spaces and times of the school. 


\section{Acontecimiento y visualidad en la es- cuela: un estudio sobre las imágenes de una ocupación imagética}

\section{VICTOR JUNGER}

\section{Resumen}

Busco pensar la multiplicidad de relaciones establecidas entre los practicantes y las imágenes fotográficas en medio a la ocupación imagética realizada en el colegio, en el ámbito de mi investigación de maestría, tomando su aparición momentánea como acontecimiento de creación de la escuela, así como de las visibilidades presididas en sus contextos. Para ello, sólo me detendré sobre los desplazamientos y desapariciones de las fotografías en el dispositivo de la ocupación, así como sobre las rasuras e inscripciones marcadas en la superficie de las imágenes, como indicios de un territorio dinámico, polémico, y no menos poético, de esta visualidad que, incesante, se hace instaurar en los espacios y tiempos de la escuela.

Palabras clave: acontecimiento, visualidad, escuel 
O que, de súbito, perfaz as pequenas ocasiões, o acaso dos encontros, não deixei jamais de encontrar na escola, assim como em outros espaços cotidianos, a nova tonicidade de mundo que, provisoriamente, me faz revisitar as coisas de outro modo. De súbito, naquilo onde já se espreitava o insólito, recebo a grata ocasião de uma revelação. Por vezes modesta, diminuta, mas ainda o mistério de uma revelação. Um novo sopro para tudo o que neste momento me cerca. Um pequeno irisar que não faz senão empalidecer a tez do mundo. Por instantes acreditaria: a evidência está nas coisas, como nos corpos. Mas devo considerar o enervamento epidérmico que é a raiz do mundo, como o próprio sensível que é o corpo percebido pelo sentido das coisas. A camada espessa dos cotidianos sorrateiramente muda o tom, altera a gravidade de suas cores, expressa com isto que sinto uma nova sensibilidade. Percebo a mudança antes tão diminuta e menor atravessar o horizonte da paisagem figurada. E, estranhamente renovado, retorno aos mundos agora apaziguados em outros contornos. Aconteceu.

$\mathrm{O}$ mundo que agora somos em pertencimento jamais nos parece ser o mesmo que foi desde o último instante. Vivenciamos sua renovação pela diferença que nos acontece de maneira inusitada em nossas palavras e gestos. Nosso contato, que já nos faz encontrar de outra maneira os corpos e as coisas, nos introduz em uma abertura desde então inesperada. Não poderia assim discorrer acerca deste instante de revelação sem considerá-lo comum ao toque em que apreendemos o sentido das coisas. Não poderia discorrer sobre a aparição do acontecimento sem percebê-la aninhada nesta contiguidade que pertence aos corpos. Sua revelação é impessoal porque apenas comum aos corpos dessa comunidade que somos em pertencimento. Estamos como que em contínua formação nisto que 
entre nós é produzido. A profusão de imagens advindas deste instante, como também aquelas nascidas em outras ocasiões, são para a cotidianidade o remanescente do acontecimento que aos poucos se perde na margem obscura do esquecimento.

Não fossem tão correntes diante de tudo que nos deparamos, dificilmente poderíamos considerar a significância destas transformações. Porque sua aparição acontece de maneira extraordinária, podemos então apreender seus efeitos realizados na alçada dos mundos. Porque nos acometem sempre que voltados para experiência, elas de pronto constituem o cotidiano dos mundos. As imagens que a partir daí são produzidas, assim como tudo o que as mobiliza, não cessam de nos surpreender. São parte desta apreensão em que se revela o instante, produzidas como que em pertencimento à sua aparição. O olhar que percorre cuidadosamente os cotidianos não se furta a encontrar detalhes que lhes são improváveis, como não se esquiva de acontecimentos que lhes são estranhos, envolvendo-se de forma inevitável nesses incidentes que ultrapassam os limites dos possíveis, para encontrar aí o instante em que o mundo se revela outro em cada corpo e objeto ${ }^{2}$.

São habituais os afazeres e as rotinas que reconheço possíveis à sua permanência, mas de uma permanência que não cessa de revelar o mundo como outro entre os corpos e as coisas. O que se toma por corriqueiro e ordinário são igualmente esses incidentes que se dão para a vida cotidiana como inusitados e extraordinários. Assim como as imagens que aí circulam, são habituais por seu pertencimento ao mundo, mas, produzidas em meio aos acontecimentos, tornam-se também capazes de nos surpreender. De todas as imagens nascidas dos acontecimentos, não deixamos de nos deparar com aquelas que, insidiosamente, afirmam sua própria criação. Essas imagens são igualmente a afirmação das visibilidades de mundo ainda em curso, na medida em que deflagram as possibilidades poéticas de criação desta visibilidade, como a potência de existir e habitar os mundos na alçada de seu desvelo.

Este trabalho procurará apresentar em sua análise como as condições em que a imagem se dispõe no mundo não passam de um indicativo de como as visibilidades de mundo são realizadas por uma determinada comunidade. Mas de modo que a imagem seja ela mesma o traço indicativo de um acontecimento de criação, intimamente realizado pela comunidade estudada, em prol de seus modos de habitar, cuidar e fruir os mundos então realizados. Sendo a imagem o traço evenemencial percebido em meio ao mundo3 ${ }^{3}$ não estaria a análise com- 
prometida em ter a imagem na sua relação com a totalidade que a cerca, embora seja vista aqui envolvida em sua aparição por tudo o que decorre na experiência. O destino das imagens será tomado por algumas séries percebidas no curso do acontecimento estudado em minha pesquisa de mestrado.

Não se poderia pensar também a profusão de imagens sem tomá-la a partir dos encontros em que percebemos sua realização. São as ocasiões dos encontros que perpetuam, extinguem ou prolongam as imagens sob outras modalidades de registros, através de diferentes espaços, desdobrando os efeitos do acontecimento pela alçada dos mundos. Assim procedeu minha pesquisa envolvida nos cotidianos escolares, compreendida de modo a cultivar esses liames que, não somente a tornam possível, como se encontram investidos na realização dos mundos. Quando voltados para o acontecimento, a experiência de criação, tocamos em algo fulcral à vida que aí reside. Onde não há apenas ação resistente, mas a inquietante afirmação da existência, a comunidade estudada tem renovada a juntura que afinal a preside e a justifica.

Essa profusão imagética também perfaz os espaços da escola através daquilo que, a despeito de sua utopia, não cessa de lhe acontecer intermitentemente. A escola é também constituída por este universo imagético na medida em que se encontra radicada nos acontecimentos de criação. Isto, pois, possibilita um olhar persuadido destes entrecruzamentos que formam a escola em sua perene multiplicidade. No domínio em que se detém essa visada, está o aprofundamento de sua visibilidade, que não poderia prescindir do contato com os estudantes. Antes, é justamente através do contato que se torna possível a visada a que se propõe este trabalho acerca da escola, realizando, entre as muitas visadas cotidianas, a compreensão mesma de sua visibilidade, como inúmeras visibilidades realizadas em uma multiplicidade de escolas.

Nesse sentido, destaco para este trabalho apenas um recorte de minha pesquisa de mestrado, que teve como objeto privilegiado os acontecimentos de criação da escola na sua relação com as visibilidades de mundo. Pensar o próprio acontecimento de criação como possibilidade de novas formas de existência, e assim pesquisar com os estudantes outros modos de ser e estar no mundo e na escola, equivalia também a conduzir a investigação ao campo das sensibilidades que se perceberiam envolvidas com os desdobramentos do acontecimento. A produção imagética, não menos extensa, me pareceu um significativo campo de tensões, na medida em que 
ainda mantém sua antiga primazia sobre o plano dos sensíveis, constitutiva do modo como a imagem veio a predominar no Ocidente. Como também encontrar nesse campo inúmeras possibilidades poéticas advindas de sua efetuação na experiência, que poderiam contrariamente evidenciar os desvios das modalidades sensíveis vigentes.

São inúmeros acontecimentos de criação que destituem as imagens de sua pretensão de unicidade sobre a vida social. Assim, considero a escola a partir de uma multiplicidade de criações que, longe de sustentá-la em um único campo representacional e imagético, sobrepõe num mesmo espaço as inúmeras escolas percebidas e realizadas. Procurei investigar os acontecimentos apreendidos em meu contato com os estudantes, nesses encontros semanais, a partir das fotografias realizadas ao sabor de cada ocasião, para em seguida lançar mão dessas imagens, nisto que tenho considerado uma ocupação imagética. Pois, justamente nesses termos, se estabeleceu para mim o campo problemático que trato em minha pesquisa como acontecimento-escola.

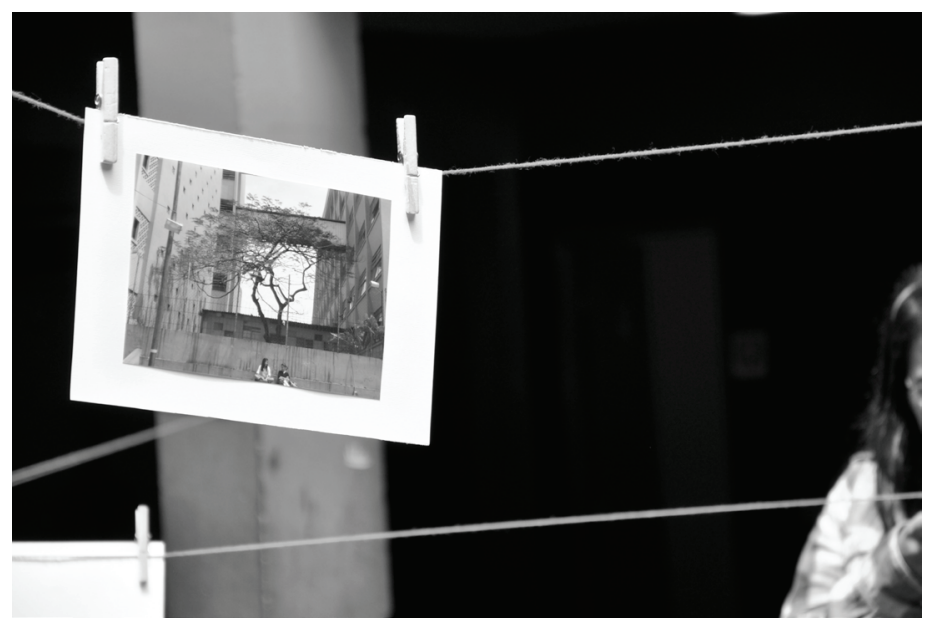

Neste trabalho, apenas me deterei sobre os deslocamentos e desaparecimentos das fotografias no curso da ocupação, bem como acerca das rasuras e inscrições marcadas na superfície das imagens, como indícios de um território dinâmico, polêmico, e não menos poético, dessa visualidade que se faz instaurar nos espaços e tempos da escola. Ocupação imagética que, conforme o trabalho de fotografia aos poucos evidencia-
Figura 1

Fonte: arquivo da pesquisa (2013) 
va, procurou esgarçar os limites de uma exposição convencional, na qual os objetos estéticos deveriam ser resguardados da intervenção dos apreciadores, além da delimitação dos sentidos sob a forma de um olhar distanciado, contrariamente possibilitando uma dinâmica suscetível ao acaso dos encontros, capaz de contemplar em sua plástica os menores movimentos da comunidade escolar.

Sendo o campo problemático o fundo virtual a partir do qual toda a pesquisa pôde ser conduzida, conviria esclarecer os desdobramentos em meio às relações dos estudantes com as imagens, no âmbito da ocupação, de modo a traçar o problema da cultura visual para a comunidade escolar estudada. Mas somente seria possível pensarmos suas visibilidades de mundo, como também apreender sua potência visual, se o dispositivo investigativo fosse também conduzido a partir das dinâmicas do acontecimento. Isso exigiria dimensionar o problema que é o acontecimento de criação da escola a partir do modo como esse dispositivo permite ser acionado pelos estudantes, especialmente no que diz respeito aos dispositivos instituídos, tanto como a escola quanto à arte, tanto às aprendizagens que promovem outras formas de saber quanto às criações que revelam novas aberturas de mundo. Assim como, a partir dos dispositivos instituídos, também pudéssemos encontrar os desvios favoráveis à realização dos acontecimentos de criação.

Não podendo ser considerada senão como problemática na sua relação com a escola, a potência de criação presente nos cotidianos parece se estabelecer inevitavelmente aquém ou além de sua tarefa. Coube à escola o exercício das faculdades de saber, sua perícia e seu aperfeiçoamento, em prol de uma consciência que não detém nada mais do que o já conhecido. Pois aquilo que se dispõe a conhecer não cessa de reduzir os mundos à univocidade que a caracteriza. A atribuição admitida pela escola em sua constituição durante a modernidade não compreenderia mais do que o exercício harmonioso e prudente das faculdades da consciência. E, por ser essa atribuição de tal modo incorporada à mentalidade social, consubstanciada em sua arquitetura e rudimentos, ainda nos cabe reiterar as discordâncias desse projeto em meio aos cotidianos escolares.

Pois os dispositivos pedagógicos vigentes terminam por exercer processos judicativos responsáveis por determinar a distância entre a matéria ensinada e o sujeito aprendiz. Processos que, a um só tempo, impõem e abolem esta distância pretensamente determinada acerca da aprendizagem, toman- 
do-a como o principal motivo de sua interrupção ou de sua insuficiência, como instaurando a partir de sua determinação os exercícios de acúmulo e transmissão de saber. Formam-se, conforme seu procedimento, os conjuntos de traços que permitiriam apreender tanto a aprendizagem quanto a ignorância, como privilegiar um modo próprio de conduzir a operação, procedimento didático, que ensine tudo a todos.

As faculdades supostamente cultivadas pela escola jamais contemplariam o seu desconhecimento acerca do mundo que, longe de se encontrar afastado de sua alçada, participa intimamente do seu processo de renovação. Na medida em que comprometidos com a transmissão do conhecimento, seus rudimentos seriam dificilmente concebidos em prol do processo de produção do saber, e assim contrários a qualquer gesto de criação que para eles escape ao esperado. Os acontecimentos de criação retomariam dessa maneira o anacronismo desta concepção de escola a partir daquilo que elevam ao grau último de afirmação. O retorno da diferença jamais abolida revela os mundos na ascensão de seu nascimento, como também a profusão poética das imagens, possibilitando a formulação de novos saberes e a elaboração de outros gestos de criação. E, assim, permitiram escoar os fluxos da vida cotidiana de modo vigoroso e assertivo neste espaço pensado inicialmente para inibi-los. Torna-se problemática qualquer gesto de criação quando pensado nos espaços e tempos da escola.

Por outro lado, não se poderia querer presenciar o livre curso das poéticas para além da arte, se mesmo a arte 4 não percebesse nisto seu movimento mais fundamental. Seria necessário aquilo que ganha inteligibilidade para encontrar na criação ${ }^{5}$ sua fronteira última e presente. Muito embora a distância percorrida por este olhar da arte já ensaie a morte da arte no cerne dos cotidianos, este movimento, ao mesmo tempo que é necessário, é igualmente comprometedor. Se o processo de criação está para alhures da arte, no insólito do mundo, pode advir de qualquer ponto, qualquer enseada afastada de seus domínios e, portanto, sempre presente na vida, assim como a vida com suas marcas na obra de arte.

Os dispositivos artísticos instituídos procuraram prever a integridade visível do objeto artístico a partir de uma ampla redução dos traços da experiência de criação, levando seus procedimentos à perda da organicidade da obra e, dessa maneira, à morte do desvelo no curso dos acontecimentos. A história da arte terminou assim por destinar à mortificação o remanescente artístico, abdicando dos traços paradoxais, de 
modo a decretar seu ressurgimento como objeto plenamente reconhecido. Nem mesmo a tarefa que na contemporaneidade é imputada à arte parece escapar ao testemunho de um pensamento que, ao enfrentar sua extinção, procura representar irremediavelmente o irrepresentável.

O seu dilema seria reconhecer em grande parte a experiência estética compreendida na sua relação com o sistema de arte. A potência poética somente traduzida sob os seus termos. O acontecimento de criação somente considerado como a verdade da arte perdida no deserto dos mundos. Se não fosse dessa maneira, deveria o sistema de arte assumir a arriscada tarefa de vasculhar em suas errâncias o artista perdido. E, por mal tê-lo encontrado, sua figura se veria aí diluída sob os traços do homem comum. Essa comprometedora evidência de que o sistema de arte é somente capaz de participar tardiamente da experiência estética, deixando ver a sua impossibilidade de garantir completa e irrestrita inteligibilidade ao curso dos processos de criação, fragilizaria os fundamentos que tão comumente justificam o encontro entre a arte e a sua consciência histórica. Assim, quando pensada para além do sistema de arte, afastada de seu domínio, a criação passa a ser problemática para a arte.

Figura 2

Fonte: Arquivo da pesquisa

(2013).

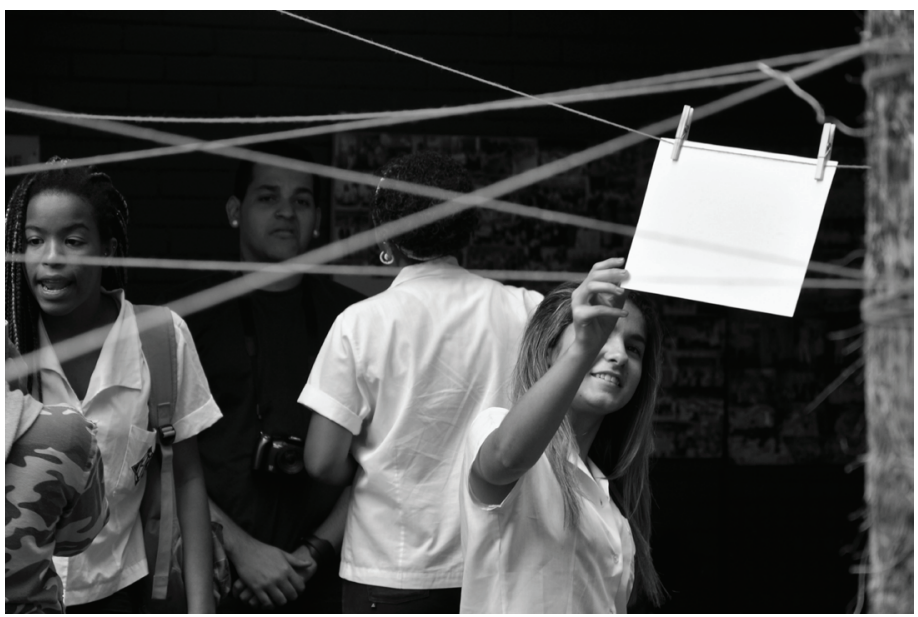

Tanto para a escola quanto para a arte, o acontecimento de criação não parece emergir sem deflagrar as suas respectivas impossibilidades. Se é preciso ter cautela para avaliar a dimensão do acontecimento a partir das duas dimensões acionadas, a fim de transitar por esse campo problemático que eu 
mesmo me imponho, seria necessário e prudente se deter sobre os movimentos micrológicos da ocupação imagética. Isto não passaria de uma pequena fração em que a escola pôde ser apreendida em sua revelação e a arte em seu elo com a comunidade. Onde, para a escola, o insólito indicia sua transformação, como também a revelação daquilo que nos incorporará a diferentes espaços e tempos. E onde, para arte, é reservada a experiência estética em superfície de contato, nesta ubiquidade epidérmica, entre os corpos de uma determinada comunidade. Ambas, escola e arte, exercidas no microcosmo dos cotidianos escolares.

O que destaquei a respeito tanto da escola quanto da arte, a partir de seus dispositivos vigentes, são os riscos a que estaria sujeita a atualização do acontecimento estudado em minha pesquisa de mestrado. A partir dos dispositivos instituídos, podemos dimensionar alguns dos enfrentamentos vividos por entre os cotidianos que, voltados à atualização dos acontecimentos de criação, terminam por destinar parte de suas realizações à inexistência. Além de tomar em consideração, com a análise dos dispositivos, as séries de realizações que numa visada mais ampla passariam desapercebidas, já que destituí-las de sua existência me parece ter estreita relação com o fato de não serem sequer apreendidas. Assim, a pesquisa procurou investigar o que aconteceu com as imagens durante a ocupação imagética, tomando o seu destino como traços e indícios de realizações que também respondem a estes enfrentamentos cotidianos, aproveitando-se desta ocasião para conduzir, no âmbito das visibilidades, o dispositivo de acordo com seus desejos e interesses. A pesquisa, dessa maneira, procura conhecer a comunidade escolar e suas visibilidades de mundo pelo modo como enfrentam os dispositivos vigentes, apropriando-se do destino das imagens.

A pesquisa de mestrado que tomo como referência para este trabalho foi desenvolvida em um colégio da rede pública de ensino do estado do Rio de Janeiro - Colégio Estadual Júlia Kubitschek $^{6}$. Em seus cotidianos procurei transitar por estas criações de contato que são os encontros com os estudantes, conforme aprofundava o engajamento investigativo, apreendendo o campo problemático desse estudo que consistia em compreender as visibilidades de mundo próprias ao espaço escolar. Envolvidos em nossos encontros semanais, tendo como 
principal convite a fotografia, realizamos um número significativo de imagens do colégio que, ao final de um extenso período, nos conduziria à ocupação do espaço escolar por meio de imagens. Tal feita já surgia inicialmente como possibilidade de desfecho para nossos encontros e, conforme passavam os meses, tornou-se necessária à conclusão do processo.

Além do mais, a ocupação por fotografias passou, num dado momento, a ser o elo concreto que justificava nossas reuniões e nos caracterizava como grupo, também incorporando outros estudantes que, interessados, aí percebiam a possibilidade de se aventurar em novas dinâmicas. Conforme desenvolvíamos o trabalho, outros grupos de estudantes foram incorporados à pesquisa, tornando ainda mais complexo o processo de produção de imagens elaborado acerca da escola. Mas a ocupação imagética não se estabeleceu apenas como meio através do qual o acontecimento de criação da escola poderia ser apreendido. De maneira menos clara, mas não menos presente, ela também guardava em sua produção, tanto para os estudantes envolvidos quanto para a comunidade escolar, os possíveis de um empoderamento, fugaz e pregnante, de seus modos de ser e estar no colégio.

Figura 3 Fonte: arquivo da pesquisa (2013)
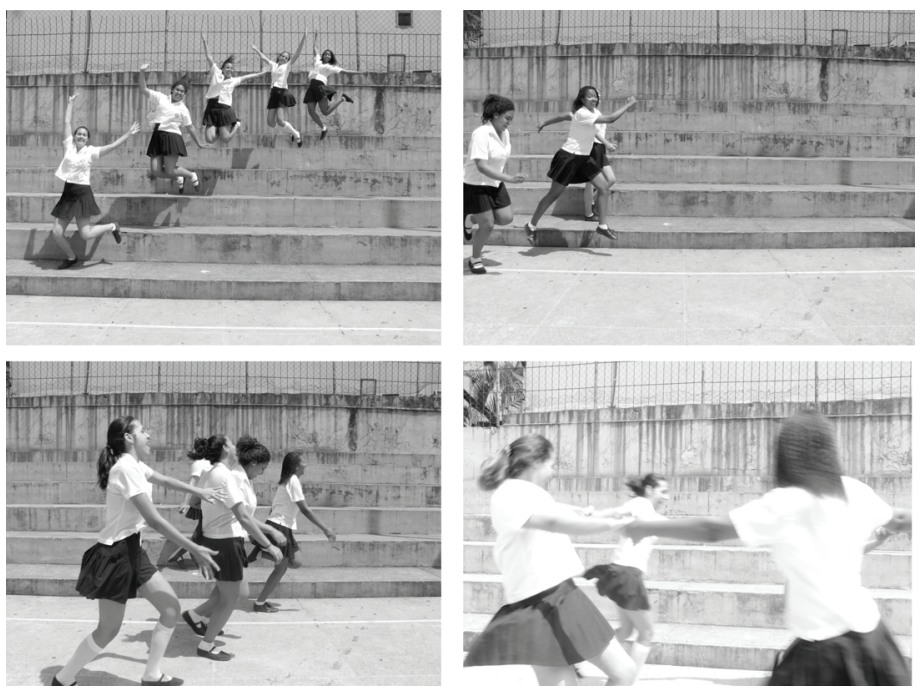

Composta por 81 fotografias do espaço escolar, a ocupação concentrou parte destas imagens em uma instalação confeccionada por fios vermelhos no centro do primeiro pavimento, 
distribuindo o restante delas por entre paredes, banheiros, refeitório, corredores e quadra de esporte. Os estudantes, que produziram estas imagens, estavam livres para concentrá-las em um determinado ponto ou expandi-las para as demais áreas do colégio, fazê-las se perder em algum corredor ou destacar sua presença pelas vias de maior circulação no colégio, como pensar a pertinência ou não de cada fotografia para o local selecionado, se houvesse nessa relação entre imagem e espaço algo para ser tematizado. Todo este dinamismo foi responsável por fazer ressoar os traços evenemenciais do que pôde ser vivenciado mutuamente pela comunidade escolar: acontecimento-escola.

Dessa maneira, compreendo ser o problema abrangido à comunidade escolar, realizado pela efetuação de um acontecimento de criação capaz de produzir outras visibilidades, a partir deste contato e deste desdobramento provocados pelas imagens fotográficas. Não concebendo simplesmente seus efeitos apenas através dos suportes de registros, mas tomando os diferentes desdobramentos das imagens por entre os fluxos da vida cotidiana, que intensificariam ou restringiriam processos amplamente desenvolvidos na alçada dos mundos. Como as imagens não se limitariam à transposição de um registro a outro e, tampouco, à sua própria materialidade, elas consagrariam a confluência dos processos pelos quais a vida faz vigorar suas maquinações, já que por meio destes processos puderam ser produzidas e renovadas de maneira intermitente. Tais efeitos de dispersão, em meio aos cotidianos, se veem muito frequentemente exercidos sob a forma de imagens sonoras, narrativas, performáticas. São essas imagens que, ruidosas e moventes, nos permitiriam perceber o problema acontecimento-escola em um insidioso descompasso para com as imagens fotográficas.

É importante destacar que há na imagem fotográfica uma imobilidade que não detém apenas o movimento do mundo, mas o fixa em seu enquadramento, de modo a realizar uma motricidade eminentemente óptica ${ }^{7}$. Como também é seu emudecimento que não extingue em absoluto os alaridos e as vozes, mas nos possibilita antever o átimo em que a fala é gestada por um silencioso e profundo rumor. A fotografia parece opor contra os fluxos da vida cotidiana sua resistência aos ruídos e às vozes, sua captura imediata aos movimentos e às velocidades, mantendo-se como uma visada que lhe é aparentemente fiel e, ao mesmo tempo, estranha. Entretanto, ela mesma não deixa de portar as marcas desta visibilidade, deste 
contato com os sensíveis, sob um registro que tomamos como predominantemente visual. É nesse sentido que a fotografia parece conservar as marcas da luz nas quais os mundos, impassíveis e fecundos, se tornam revelados à percepção.

Defendo assim que as fotografias realizadas pelos estudantes preservaram os resquícios de sua aventura por estes mundos sempre habitados, inquietante exploração acerca daquilo que os instiga, de sua persistente tentativa em fazer do espaço habitado a distinta imagem de seu gosto. Como é igualmente mantida essa presença, ela mesma dissuadida pelos extremos do gesto fotográfico, da evanescente beleza do universo perceptivo. Mesmo diante de um cenário que nos era comum, mesmo reiterando algumas opções fotográficas, não se poderia encontrar em suas fotografias qualquer vestígio de uma simples reprodução do olhar. Suas fotografias não seriam nada mais que o remanescente de uma empresa cultivada em íntima aprendizagem de criação, na medida em que deflagram, a partir do conjunto das imagens, os seus processos de captura e invenção. Além dos traços fotográficos, também compreenderem tanto o jogo de corpo relativo aos percursos empreendidos pelos estudantes quanto a multiplicidade de entendimentos apreendida nesta visada, que, de forma irrestrita, se vê exposta à objetiva.

Figura 4 Fonte: arquivo da pesquisa (2013)
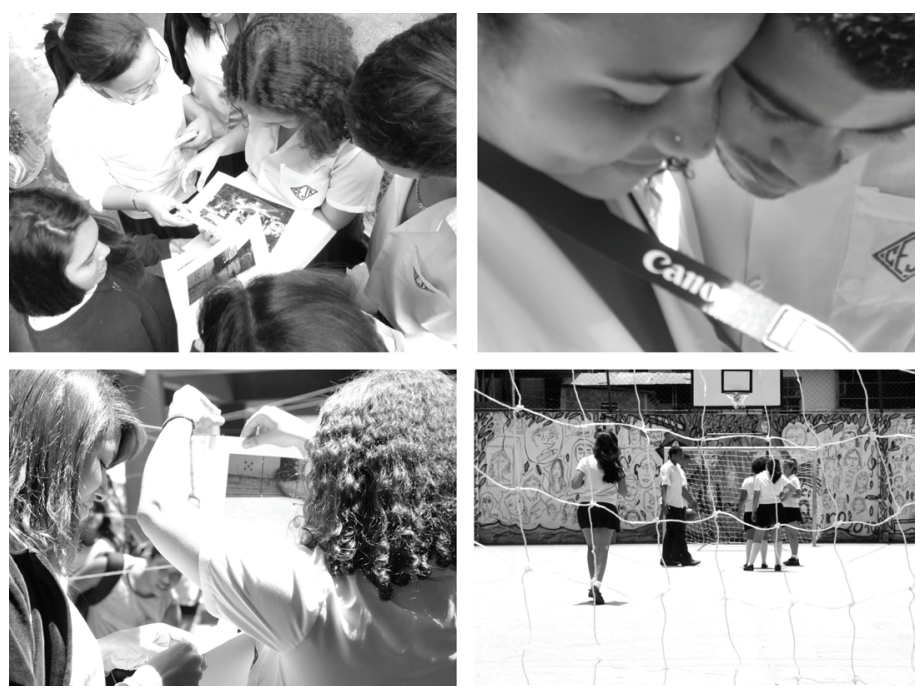

Do volume de imagens produzido ao longo de nossos encontros, a disseminação das fotografias pelo espaço escolar 
pareceu ser a melhor forma de acionar o problema acontecimento-escola, já que o contato entre imagens cotidianas e fotografias, a reiterada tematização do espaço, nos conduziria de imediato à proliferação dos estranhamentos no plano do visível. Sendo incompossível o modo pelo qual apresentamos as fotografias, a ocupação imagética seria capaz de criar condições para a efetuação de estranhamentos, pelo modo mesmo que a visibilidade escolar abrigaria as imagens produzidas. É, pois, esta multiplicidade de estranhamentos que, no desenvolvimento da pesquisa, terminaria por atualizar as condições de possibilidades voltadas ao aparecimento de outros mundos. Porque tais usos são incompossíveis para a visualidade escolar, tornava-se possível vivenciar uma proliferação de produções desencadeada pelo contato entre imagens cotidianas e imagens fotográficas. Através deste estado de coisas, pensei ser possível apreender a visualidade constitutiva do espaço escolar, como é especialmente tratada aqui: um acontecimento de criação da escola.

Desde a incomum e inusitada disposição das imagens, como o descompasso entre as fotografias e as imagens cotidianas, acredito termos acionado as condições de possibilidade em que a comunidade escolar seria capaz de vivenciar o campo problemático do acontecimento. Se se tornava fundamental perscrutar os modos pelos quais a comunidade pôde apreender tais estranhamentos, os sentidos pelos quais se percebia instalada no problema, convinha inicialmente seguir os traços de seu engajamento através de seus efeitos atualizados no curso da ocupação. Tomei dessa maneira como índice de seu engajamento o destino investido pelas imagens, as pequenas resoluções perpetradas neste contato com o problema, que ocorre prolongar a revelação do acontecimento em franca atualização dos gestos, superfícies e visibilidades. Esses indícios, uma vez considerados traços evenemenciais, estariam relacionados ao problema que mutuamente vivenciamos nos espaços e tempos da escola, permitindo-nos, assim, percorrer o largo de seus desdobramentos, sem negligenciá-los, de modo a perpetuar ou amenizar, fecundar ou extinguir, o atual de seus efeitos.

Muito embora aqui exista o risco de uma visada excessivamente ampla para o problema, penso que os efeitos relacionados ao acontecimento podem ser mais bem compreendidos se destacados dois sentidos do que foi em grande parte atualizado na ocupação. Ambos os sentidos apontam para intervenções que se deram ao nível de duas séries, elas mesmas entrecruzadas ou afastadas no contexto do problema 
acontecimento-escola, exercendo sua mútua diferença sob a multiplicidade dos modos de apreensão do problema. Não é excessivo afirmar que boa parte das séries percebidas durante a ocupação se deu como efeito de circulação das imagens: seja pela proliferação dos deslocamentos por entre inúmeros pontos do espaço escolar, seja pelos inesperados desaparecimentos ao longo de todo o processo, foi a circulação das imagens que esteve em jogo no próprio ato de ocupar as paisagens existenciais. Por outro lado, deparei-me com uma pequena parte destas séries efetuadas sob a própria superfície da imagem: tanto pelas inscrições que reiteravam a composição da fotografia quanto pelas ranhuras que faziam desaparecer seus elementos compositivos, também foi a superfície das imagens que sofreu diferentes intervenções pelo cerco desta ampla contenda. Designo, assim, como efeito de circulação a dimensão do problema que percorreu a dupla série espaço e imagem, e como efeito de superfície a dimensão do problema que se dispôs na dupla série fotografia e intervenção.

Sendo os efeitos de circulação a série atualizada entre fotografia e visualidade espacial, neste percurso do atual em que se torna visível o campo problemático, a comunidade escolar pôde aqui tomar parte do dispositivo estendendo, complicando ou obliterando a presença produzida por esse volume de imagens. Não se poderia ter como pequenas resoluções para o problema, o estranho que seriam estas fotografias na paisagem existencial, senão o gesto intimamente produzido no decurso do acontecimento de ocupação. A série imagem e espaço não seria nada mais que o prolongamento de um problema, em que podemos perceber de outro modo o espaço habitado por nossas imagens. Do mesmo modo que a imagem convoca ou dispensa os sentidos nesse problema, que é seu estreito contato com o espaço. Quando percebi que as imagens dispostas na instalação do centro do pátio eram justamente as imagens caídas pelo chão no dia anterior, compreendi neste momento que o problema da ocupação imagética poderia ainda perpetuar-se graças ao esforço dos escolares em mantê-las visíveis. Do mesmo modo que alguns professores e estudantes sinalizavam a possibilidade de perdermos as fotografias se as deixássemos expostas ao mau tempo, poderia aqui dizer da ocupação o desdobramento do problema para salvaguardar essas imagens que nos permitiam ver de outro modo o espaço por nós habitado. Tais efeitos se veem gestados neste estranhamento entre a ocupação imagética e a visualidade própria aos cotidianos escolares: a circulação das imagens não passa- 
ria de uma sucessão de soluções ao pequeno desvio provocado na paisagem existencial da escola.

Do momento em que instalamos as fotografias nas dependências do colégio à sua completa retirada, os deslocamentos não cessaram de atravessar e constituir o processo de ocupação das visibilidades escolares. Pela intensidade com que as imagens foram mobilizadas, sem encerrarem por completo seus deslocamentos, convém acentuar o quanto esta visibilidade de mundo em que se faz escola diz respeito também às diferentes formas de existir próprias a sua espacialidade. Não acredito ser suficiente considerá-los apenas como forma de rarefazer ou conservar o campo visual, tampouco tomá-los pela aversão de alguns grupos a seus elementos compositivos. Seria vago situar o seu jogo polemológico apenas no âmbito de uma apreciação estética, e sim tê-los em vista como resposta ao problema radicado nos modos pelos quais a comunidade faz da escola um lugar habitado. Afinal, muito do que pôde ser percebido dos deslocamentos advém de uma tentativa de reinserção das imagens no âmbito da ocupação, e assim de resistir em salvaguardar isto que nos faz apreender por diferentes vias os cotidianos escolares.
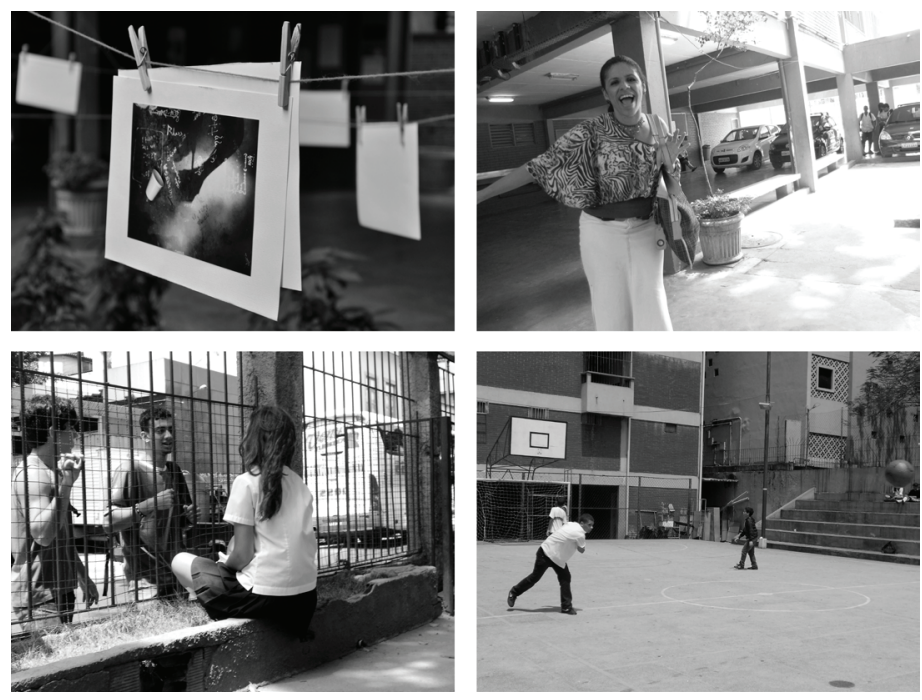

Figura 5

Fonte: arquivo da pesquisa (2013)
Parte da dinâmica da ocupação se desvela como que em pequenas ocasiões: na manhã do segundo dia de ocupação, uma das imagens caídas no chão, fotografada no final do dia 
anterior, surgiu inesperadamente na instalação do centro do pátio. Ocultada parcialmente atrás de outra fotografia, escondia em sua superfície a marca de uma sola de sapato. Isto, pois, revelava o cuidado com que havia sido recolocada na instalação, sem que o trecho onde foi danificada estivesse visível. Ao invés de retirá-la da ocupação, esse mesmo gesto a manteve em circulação de um modo ainda muito particular. Nos demais dias, a fotografia poderia ser vista com a marca do tênis de um ponto a outro da ocupação. Para os problemas que se multiplicavam no universo das imagens, nesta ocasião atualizados, a comunidade escolar não cessava de tomar parte da ocupação imagética com seus gestos e resoluções, conduzindo as imagens fotográficas por todo o espaço escolar através da fugacidade de seus entendimentos, desejos e interesses. Penso que, de certa maneira, muitas destas ações se deram como o tácito consentimento para com as visibilidades atualizadas na ocupação, pelas quais o desvelo interessava se prolongar ainda mais em seu universo perceptivo, a extensão deste problema que se dispõe de forma inusitada na sua relação com as visibilidades comumente instauradas pela instituição escolar.

Também foi possível perceber, na alçada dos efeitos de circulação, o progressivo desaparecimento das fotografias, envolvido numa aparente retirada dos espaços e tempos da escola, que se fez desdobrar deste contato com o problema a seleção de todo o volume de imagens. Pelo modo como se desvelou esta operação de seleção, não penso ser suficiente considerarmos os desaparecimentos apenas sob os termos de uma supressão do material visual, tampouco o urgente afastamento de algumas imagens do espaço escolar, admitindo como única reação a tentativa de preservar suas visibilidades de mundo contra qualquer possibilidade de mudança. Muito embora sejam estes aspectos também legítimos para se pensar os desaparecimentos, tanto a recusa quanto a aversão ao que nos acontece durante ocupação, boa parte do que pareceu mobilizá-los foi contrariamente a tentativa de preservar as imagens de possíveis avarias. Longe de apenas atenuar nosso contato para com o acontecimento, de resistir aos menores efeitos de mudanças, os estudantes preservavam as imagens por serem elas mesmas capazes de acionar outras experiências de mundo. Isto, pois, não é nada mais que a tentativa de fazer perpetuar os efeitos evenemenciais para além de sua possível extinção.

E, aqui, a dinâmica igualmente se desvela em uma pequena ocasião: como algumas estudantes me deram a conhecer, outras afirmaram realizar, os desaparecimentos significavam 
a retirada de circuito das imagens com o intuito de preservá-las. Era evidente em suas ações o interesse que tinham em determinadas fotografias, as quais lhes pareciam muito caras a ponto de recusarem deixá-las expostas na ocupação. Fui ao encontro das estudantes do terceiro ano responsáveis pela retirada das imagens e, ao serem inqueridas a respeito, argumentaram de imediato que as fotografias seriam com certeza destruídas pelos demais estudantes do colégio. Poucas imagens tiveram de fato o destino que tanto temiam. Não há aqui apenas o urgente afastamento das imagens, a impassível rejeição de seus elementos compositivos, sua presença que parece extinguir-se no cerco da ocupação imagética. Os desaparecimentos passam ao largo de uma simples rarefação do campo problemático. Não há simplesmente a produção de ausências no cerne do acontecimento de criação. Ocorre, sim, percebê-los como prolongamento evenemencial que ultrapassa os limites dos circuitos inicialmente pensados para, dessa maneira, fazer ressoar seus efeitos muito além do espaço escolar. Não se pode ignorar que estes meninos e meninas buscaram conservar as fotografias em outros espaços e tempos. Há com os desaparecimentos das imagens a extensão do campo problemático, convidando-nos a pensar a convergência deste acontecimento para com diferentes acontecimentos em outras regiões da cidade. É novamente o cuidado que não faz senão atravessar parte da dinâmica da ocupação e, dessa maneira, determinar os destinos das imagens.

Tomando, por outro lado, os efeitos de superfície através da série atualizada entre intervenção e fotografia, neste remanescente do atual em que se faz visível o gesto problemático, os escolares se investem sobre o contato com a imagem pelo golpe que torna possível o desvio de uma determinada composição fotográfica e, com isso, de sua tentativa de tematização espacial. Convém ser enfatizado nesse efeito seu caráter propriamente superficial, já que ele mesmo termina por instaurar sua problemática no âmbito da composição fotográfica. É, pois, a própria intervenção que provoca um desvio investido sobre a composição da imagem, a organização de seus elementos estéticos, para em seguida dotá-la de um novo modo de tematização. Na medida em que tal composição passa a adquirir outros sentidos a partir do que nela se imprime, é ostentada a intervenção como o golpe de seu não pertencimento pelo que lhe é deliberadamente impresso, reconhecemos de pronto em sua investida que não se poderia com facilidade esgotar as suas possibilidades de compreensão. Nessas visibi- 
lidades de mundo que se desvelam sob o curso da ocupação imagética, as fotografias adquirem novos modos de perceber o espaço a partir das intervenções produzidas no próprio corpo da imagem. É através das intervenções em superfície que o gesto de ocupação passa a ser reapropriado pelos escolares. Sendo a série entre fotografia e intervenção nada mais que o prolongamento de um problema em que podemos perceber de outro modo o espaço por nós habitado, percebemos nas ranhuras e inscrições sua investida sobre o gesto da ocupação que torna possível o desvelamento do mundo, como efeito evenemencial que nos deixa ver igualmente a investida da comunidade escolar neste contato com o problema da visibilidade e, por conseguinte, com o problema da criação da escola.

Quanto às poucas imagens com inscrições em sua superfície, se tornou evidente não apenas a capacidade da fotografia em resistir aos golpes investidos na ocupação, sua sobrevivência durante o acontecimento, como o próprio gesto de ocupar o espaço reiterado pelo não pertencimento da inscrição. $\mathrm{O}$ gesto de ocupar o espaço passa a ser subvertido pela inscrição ao tomar parte desta presença a que não é em pertencimento, a presença da imagem, imprimindo assim em sua investida um desdobramento outro na paisagem existencial da escola. E, se destaco o não pertencimento da inscrição à imagem, é por justamente perceber nesta condição o exercício de uma diferença que, ainda em nosso primeiro contato, não permite reduzir suas possibilidades de compreensão a uma única versão do seu expediente. Não há aqui a tentativa de obliterar a tematização do espaço provocada pela fotografia, nem mesmo de rebaixar simploriamente os seus elementos compositivos, senão para produzir um novo desvio que possibilite ver de outra maneira os espaços tematizados e, assim, perpetuar seus efeitos por meio de diferentes desdobramentos.

Uma pequena ocasião: à procura das fotografias de um determinado estudante, dirigi-me ao corredor do segundo pavimento onde até então se localizavam. Para minha surpresa, chegando lá, encontrei seus retratos parcialmente rabiscados. Aproximei-me para averiguar do que se tratava tal investida: no retrato de uma professora havia a seguinte inscrição escapando de sua boca - "Buhhh". Ela procurava ironizar a imagem, lançando mão da posição em que a professora fora flagrada. Na medida em que o objetivo deste gesto não é o desparecimento ou a destruição da imagem, sua sobrevivência no dispositivo era afinal pertinente, o gesto pode ser compreendido como outro modo de se tomar parte dos efeitos 
evenemenciais que percorrem toda comunidade escolar. Seria insuficiente pensar tais inscrições apenas como o dano ou o golpe deliberadamente empreendido por grupos rivais, ou mesmo como a réplica dos estudantes contra as hierarquias constitutivas do espaço escolar. Muito embora estes golpes e danos pertençam ao drama da vida nas escolas, não penso que tal atitude possa esclarecer parte da complexidade destes investimentos, especialmente no que se refere ao campo problemático aberto através da ocupação imagética. A superfície da imagem é, afinal, preservada por este gesto para que a inscrição possa ser exercida. Ela está longe de abdicar dos elementos compositivos para ser inscrita. Mas convém à inscrição se integrar ao corpo da imagem como aquilo que não é em pertencimento. Ela faz assim pertencer o seu não pertencimento ao reiterar a presença da imagem como aquilo que lhe é estranho. Tal artifício só tende a perpetuar os estranhamentos no curso da ocupação imagética.

$\mathrm{Na}$ alçada dos efeitos de superfície, também pude encontrar imagens que portavam ranhuras e raspagens, poucas, diante de todo o volume de fotografias, persistindo ainda por tempo considerável nesta reiteração da presença que é a da imagem. Fez-se desdobrar o prolongamento do problema no âmbito da composição imagética por via de uma intervenção completamente diferente daquela em que se viam exercidas as inscrições. O gesto de ocupar parece contrariamente trazer para a alçada dos mundos um problema de que não se convém tomar parte. No entanto, as raspagens da superfície persistem em preservar o corpo da imagem a despeito do que restou dos seus elementos compositivos. Por tal feita, a permanência da imagem no dispositivo de ocupação, não se pode considerar as ranhuras simplesmente como a dispensa de alguns elementos compositivos, exemplar de uma ínfima sanção, sem percebermos em seu gesto os efeitos capazes de atualizar os possíveis de sua circulação pelo espaço escolar. Há aqui o prolongamento de um problema que dá a ver em nosso contato outras visibilidades de mundo.

Por intermédio de alguns estudantes tive conhecimento de algumas imagens cujos rostos retratados teriam sido apagados. Ao lançar o olhar sobre elas, imaginava que as raspagens dos rostos teriam sido produto de um enfrentamento entre grupos rivais de estudantes. Com a ajuda de algumas estudantes pude averiguar o acontecido: certificarem-me de que este movimento teria sido obra dos estudantes retratados. Os que haviam raspado seus rostos não tinham a pretensão 
de serem vistos na imagem. Não se trata aqui de um enfrentamento com a ausência de que seríamos supostamente constituídos, nem mesmo o exercício de um procedimento que afasta qualquer entendimento acerca da imagem. Mais que isso, ao raspar a superfície, expor o branco subsumido pela fotografia, tal gesto não fez senão presente as possibilidades daquilo que não podemos ver. É o invisível que aqui ganha a superfície. Os rostos poderiam ser incorporados pela imagem e, por não serem definitivamente determinados, são mantidos em sua potencialidade de ser em relação com os demais elementos compositivos. São virtualmente os rostos de boa parte da comunidade escolar que, num único golpe, ganham presença pelo branco.

Figura 6
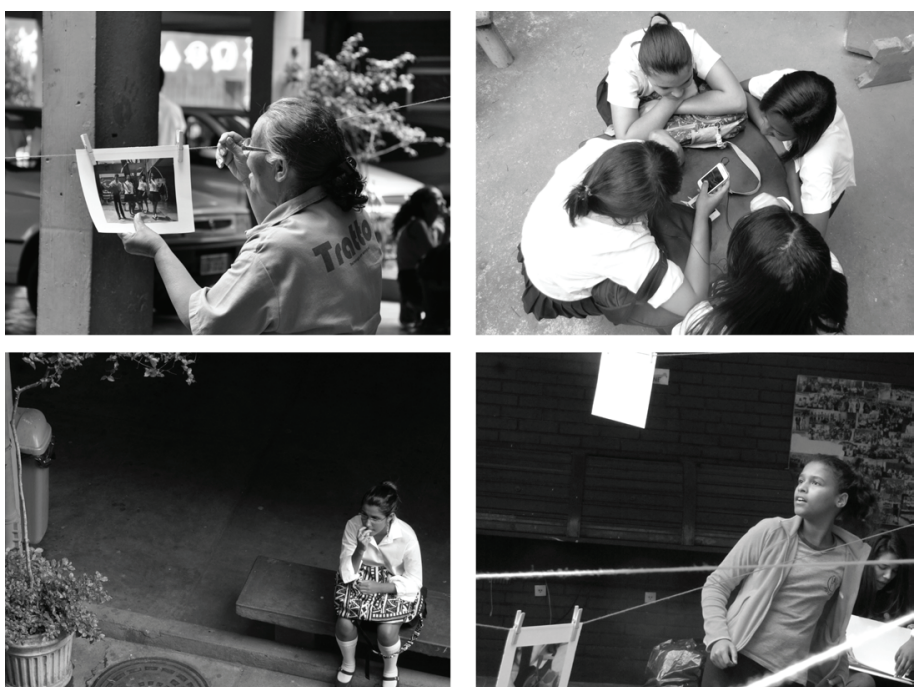

Ao averiguar os destinos das imagens, seus deslocamentos e desaparecimentos, suas inscrições e ranhuras, este trabalho procurou refletir a um só tempo sobre as visibilidades de mundo e o potencial visual, modos de ver e estar nos cotidianos, eles mesmos próprios à comunidade escolar do CEJK. Para tanto, foi necessário conduzir um dispositivo no qual a disseminação das fotografias pudesse acionar o problema acontecimento-escola. Isto nos ofereceu a plataforma de perscrutação que terminaria por se dar pelo viés poético, de uma aproximação com a escola que se faz em criação estética, desde já como obra estendida por todo o processo, o que evi- 
dencia a pertinência do seu estudo no âmbito das artes como da visualidade escolar. Investidas sobre os corpos e falas, as imagens perfazem os fluxos contingenciais permanentemente conduzidos ao sabor dos acontecimentos. Nascem de súbito para em seguida desaparecer. Aderem à matéria a fim de garantir sua permanência. Constituem um universo imagético que, em prol de novos modos de ser, cristalizam os efeitos evenemenciais em paisagens ainda em curso. Estilhas que, na margem fronteiriça do mar, surgem fulgurantes sobre o dorso das ondas. A um só tempo o problema e a experiência estética, a aprendizagem e a criação, nada mais que reunidos nos espaços e tempos da escola.

É dessa maneira que procurei investigar o acontecimento-escola na sua relação com as visibilidades de mundo, através dos entrecruzamentos das aprendizagens e das criações cotidianas por via do contato, mas de um amplo processo de produção que mais nos envolveu do que nos distinguiu. Dada a amplitude deste trabalho, pouco do aspecto poético, a potência de se fazer novos modos de ser e estar no colégio, pôde aqui ser devidamente contemplado. A reflexão acerca dos deslocamentos e desaparecimentos pretendeu acentuar as possíveis relações nesta forma muito particular de habitar o espaço, como, das ranhuras e inscrições, procurei versar acerca do seu não pertencimento para com o próprio gesto de ocupar. Foi essa a tentativa de pensar tais movimentos como intimamente aninhados à vida nas escolas.

Resta ao final destacar o inefável da aprendizagem que, inevitável, se deu no transcorrer da investigação, a emergência deste olhar que nasce pregnante para os sentidos, destes novos modos de ver e sentir com o que efusivamente emerge no extraordinário dos cotidianos e que, por mais que seja dito, há sempre mais a se dizer.

Este trabalho se revela como mais um remanescente em obra de aprendizagem.

\section{NOTAS}

1 Texto apresentado em versão preliminar no IV Colóquio Internacional Educação e Visualidade: Pedagogias em Trânsito, realizado na Universidade Federal de Santa Maria, quando pôde contar com contribuições significativas ao seu atual formato.

2 A relação do instante para com o mundo, longe de reforçar aquilo que já se dá como existente, se estabelece como esta diferença que não cessa de conduzi-lo à aparição de outros mundos, bem como à sua possível renovação pelo que deixaria de ser em seus cotidianos. Mas isto ocorre de um modo em que o mundo não realiza propriamente a atualização como um possível que se oponha à sua condição de ser. O instante termina por mover pela diferença tudo o que se faz visto e dito entre os possíveis do mundo. 
3 Recorro aqui à leitura que Deleuze $(2006$, p. 82$)$ desenvolve sobre a ideia de mundo elaborada por Leibniz, pela qual o mundo pode ser concebido através daquilo que exprime seu universo de possíveis. Tal modo de expressão apenas se realizaria pelo que é dado na atualidade como os possíveis dos nossos gestos, falas e percepções. Nesse sentido, a ideia mesma de totalidade de mundo é destituída de seu caráter absoluto e passa a ser compreendida como totalidade relativa a outros mundos. Não há totalidade que possa ser realizada senão a partir daquilo que se dispõe como atual. Não se poderia determinar a totalidade do mundo sem que, antes, o atual já houvesse se determinado. Por sua vez, o fundo virtual abriga esta totalidade como aquilo que não a determina. E sim, como aquilo que a conduz a se diferenciar permanentemente.

4 Muito embora, nesta apresentação, me refira à arte como sistema voltado a sua própria capitalização e inteligibilidade, todo o trabalho está radicado no entendimento de que a arte não não passa do gérmen da experiência estética, tendo em vista ser ela mesma o prolongamento do acontecimento que se dispõe em obra de criação.

5 A criação aqui compreendida está intimamente relacionada aos acontecimentos de renovação da vida, diferenciação correlativa do atual e do virtual, pela qual as sensibilidades de mundo são constantemente realizadas.

6 Localizado no centro do município do Rio de Janeiro, próximo à Central do Brasil, onde foi possível estar em contato com jovens de diferentes regiões da cidade e de outros municípios da região metropolitana. Boa parte de seus estudantes é moradora da zona norte e oeste, o que exige que essas normalistas necessariamente transitem pela cidade, realizando extensos trajetos urbanos, antes de alcançar o colégio. Há, portanto, um cosmopolitismo próprio aos mundos que não cessam de se desvelar nos espaços e tempos do colégio.

7 “"...] tudo que se passa no interior do enquadramento morre de maneira absoluta, uma vez ultrapassado esse enquadramento. Quando se define a Foto como uma imagem imóvel, isso não quer dizer apenas que os personagens que ela representa não saem: estão anestesiados e fincados, como borboletas" (BARTHES, 2012, p. 57).

\section{Referências}

ALVES, N. Decifrando o pergaminho - o cotidiano na escola nas lógicas das redes cotidianas. In: OLIVEIRA, I. B; ALVES, N. Pesquisa no/do cotidiano das escolas - sobre redes de saberes. Rio de Janeiro: DP\&A, 2001.

BARTHES, R. A câmara clara: nota sobre a fotografia. Rio de Janeiro: Nova Fronteira, 2012.

CERTEAU, M. de. A invenção do cotidiano: artes de fazer. 3. ed. Petrópolis, RJ: Vozes, 1998.

DELEUZE, G. Diferença e repetição. 2 ed. Rio de Janeiro: Graal, 2006.

.Lógica do sentido. 4. ed. São Paulo: Perspectivas, 2007.

. Proust e os signos. Rio de Janeiro: Forense Universitária, 2010.

DERRIDA, J. Pensar em não ver: escritos sobre as artes do visível. Florianópolis: Ed. da UFSC, 2012.

DIAS, S. A Lógica do acontecimento: Deleuze e a filosofia. Porto: Edições Afrontamentos, 1995. 
GALEFFI, D. A. O que é isto - a filosofia de Husserl? Ideação, Feira de Santana, n.5, p. 13-36, jan./jun. 2000.

GEERTZ, C. A interpretação das culturas. Rio de Janeiro: Livros Técnicos e Científicos Editora, 1989.

HEIDEGGER, M. A origem da obra de arte. São Paulo: Edições 70, 2010.

KRAUSS, R. O fotográfico. Barcelona: Editorial Gustavo Gili, 2012.

MERLEAU-PONTY, M. O visivel e o invisível. São Paulo: Perspectivas, 2009.

OLIVEIRA, I. B. de. Currículos praticados: entre a regulação e a emancipação. Rio de Janeiro: DP\&A, 2003.

SOULAGES, F. Estética da fotografia: perda e permanência. São Paulo: Editora Senac São Paulo, 2010.

VICTÓRIO FILHO, A. A arte na/da educação: a invenção cotidiana da escola. 2005. Tese (Doutorado em Educação) - Faculdade de Educação, Universidade Estadual do Rio de Janeiro, Rio de Janeiro, 2005.

. Corpo escola: currículo vibrátil e pedagogia da carne. Currículo sem Fronteiras, v. 12, n. 3, set./dez. 2012.

. Pesquisar o cotidiano é criar metodologias. Educação $\mathcal{E}$ Sociedade, Campinas, v. 28, n. 98, p. 97-110, jan./abr. 2007. 
Recebido em: 25/01/2016

Aprovado em: 11/01/2017

\section{VICTOR JUNGER}

victorjunger@gmail.com

Doutorando pelo Programa de Pós-Graduação em Educação pela Universidade Estadual do Rio de Janeiro, Rio de Janeiro, Rio de Janeiro, Brasil. 